University of Wollongong

Research Online

Australian Institute for Innovative Materials -

Papers

Australian Institute for Innovative Materials

2005

Nano-structured SnO2-carbon composites obtained by in situ spray

pyrolysis method as anodes in lithium batteries

\author{
Ling Yuan \\ University of Wollongong, ly93@uow.edu.au \\ Konstantin Konstantinov \\ University of Wollongong, konstan@uow.edu.au \\ Guoxiu Wang \\ University of Wollongong, gwang@uow.edu.au \\ Hua-Kun Liu \\ University of Wollongong, hua@uow.edu.au \\ S X. Dou \\ University of Wollongong, shi@uow.edu.au
}

Follow this and additional works at: https://ro.uow.edu.au/aiimpapers

Part of the Engineering Commons, and the Physical Sciences and Mathematics Commons

Research Online is the open access institutional repository for the University of Wollongong. For further information contact the UOW Library: research-pubs@uow.edu.au 


\title{
Nano-structured SnO2-carbon composites obtained by in situ spray pyrolysis method as anodes in lithium batteries
}

\begin{abstract}
In this paper, we report on a series of $\mathrm{SnO}_{2}$-carbon nano-composites synthesized by in situ spray pyrolysis of a solution of $\mathrm{SnCl}_{2} \cdot 2 \mathrm{H}_{2} \mathrm{O}$ and sucrose at $700{ }^{\circ} \mathrm{C}$. The process results in super fine nanocrystalline $\mathrm{SnO}_{2}$, which is homogeneously distributed inside the amorphous carbon matrix. The $\mathrm{SnO}_{2}$ was revealed as a structure of broken hollow spheres with porosity on both the inside and outside particle surfaces. This structure promises a highly developed specific surface area. X-ray diffraction (XRD) patterns and transmission electron microscope (TEM) images revealed the $\mathrm{SnO}_{2}$ crystal size is about $5-15 \mathrm{~nm}$. These composites show a reversible lithium storage capacity of about $590 \mathrm{mAh} \mathrm{g}^{-1}$ in the first cycle. The discharge curve of the composite indicates that lithium is stored in crystalline tin, but not in amorphous carbon. However, the conductive carbon matrix with high surface area provides a buffer layer to cushion the large volume change in the tin regions, which contributes to the reduced capacity fade compared to nonacrystalline $\mathrm{SnO}_{2}$ without carbon.
\end{abstract}

\section{Keywords}

Nano, structured, SnO2, carbon, composites, obtained, situ, spray, pyrolysis, method, anodes, lithium, batteries

\section{Disciplines}

Engineering | Physical Sciences and Mathematics

\section{Publication Details}

Yuan, L, Konstantinov, KK, Wang, G, Liu, HK \& Dou, SX (2005), Nano-structured SnO2-carbon composites obtained by in situ spray pyrolysis method as anodes in lithium batteries, Journal of Power Sources, 146(1-2), pp. 180-184. 


\title{
Nano-structured $\mathrm{SnO}_{2}$-carbon composites obtained by in situ spray pyrolysis method as anodes in lithium batteries
}

\author{
Ling Yuan*, K. Konstantinov, G.X. Wang, H.K. Liu, S.X. Dou \\ Institute of Superconducting and Electronic Materials University of WVollongong, NSW 2522, Australia
}

Available online 24 May 2005

\begin{abstract}
In this paper, we report on a series of $\mathrm{SnO}_{2}$-carbon nano-composites synthesized by in situ spray pyrolysis of a solution of $\mathrm{SnCl} l_{2} \cdot 2 \mathrm{H}_{2} \mathrm{O}$ and sucrose at $700^{\circ} \mathrm{C}$. The process results in super fine nanocrystalline $\mathrm{SnO}_{2}$, which is bomogeneously distributed inside the amorphous carbon matrix. The $\mathrm{SnO}_{2}$ was revealed as a structure of broken hollow spheres with porosity on both the inside and outside particle surfaces. This structure promises a highly developed specific surface area. X-ray diffraction (XRD) patterns and transmission electron microscope (TEM) images revealed the $\mathrm{SnO}_{2}$ crystal size is about $5-15 \mathrm{~nm}$. These composites show a reversible lithium storage capacity of about $590 \mathrm{mAh}^{-1}$ in the first cycle. The discharge curve of the composite indicates that lithium is stored in crystalline tin, but not in amorphous carbon. However, the conductive carbon matrix with high surface area provides a buffer layer to cushion the large volume change in the tin regions, which contributes to the reduced capacity fade compared to nonacrystalline $\mathrm{SnO}_{2}$ without carbon.
\end{abstract}

(c) 2005 Elsevier B.V. All rights reserved.

Keynords: Lithium-ion; Anodes; $\mathrm{SnO}_{2}$; Composite; Carbon; Tin

\section{Introduction}

Since FUJ Photofilm published patents $[1,2]$ for the use of tin-based composite oxide (TCO) as an alternative anode material for lithium-ion batteries in 1995, a lasting interest in tin alloys and compounds has grown. As possible anodes for next generation lithium-ion batteries, tin oxide based materials show great promise for their high storage capacity [3]. However, as is always observed, the significant capacity fading of these anodes has undermined the advantage.

Many efforts have been devoted to attempts to reduce the capacity fading. Generally, two approaches have been attempted:

(1) A number of nano-structured $\mathrm{SnO}_{2}$ materials have been synthesized by a variety of methods such as sol-gel templating [4,5] and reverse microemulsion [6]. The nano-structure ensures that the Sn region is small enough initially to get a fast diffusion of lithium-ions into the electrode, and prevents the $\mathrm{Sn}$ regions from aggregating.

\footnotetext{
* Corresponding author. Tel.: +61242213017 ; fax: +61242215731 .

E-mail address: ly93@uow.edu.au (L. Yuan).
}

(2) Different matrixes which have electronic and ionic conductivity throughout the electrode have been investigated to accommodate the large volume changes have been searched. Recently, the search for a suitable matrix has been focused on carbonaceous materials which can reduce the fading in capacity to some extent $[3,7-10]$.

Following these two approaches, we aim to synthe. size a nano-structured $\mathrm{SnO}_{2}$ material, and search for a suitable matrix to accommodate the impressive volume changes. In the present study, the spray pyrolysis technique was applied to synthesize in situ a series of $\mathrm{SnO}_{2}$ carbon nano-composites at $700^{\circ} \mathrm{C}$. The spray pyrolysis in situ process ensures that the chemical reaction is completed during very short time, preventing the crystals from growing larger.

A solution of $\mathrm{SnCl}_{2} \cdot 2 \mathrm{H}_{2} \mathrm{O}$ and sucrose has been used as a spray precursor. The process results in super fine nanocrystalline $\mathrm{SnO}_{2}$, which is distributed homogeneously inside the amorphous carbon matrix. This paper reports on the formation of the composites and their electrochemical properties as anodes in lithium-ion batteries. 


\section{Experimental}

The spray precursors were prepared by mixing saturated aqueous sucrose solutions with tin(II) chloride dihydrate (Aldrich, 98\%) $1 \mathrm{M}$ ethanol solution, in $\mathrm{SnCl}_{2} \cdot 2 \mathrm{H}_{2} \mathrm{O} /$ sucrose in weight ratios of 100:0, 60:40, 40:60, and 10:90, respectively. The $\mathrm{SnO}_{2}$ pure sample and $\mathrm{SnO}_{2}$-carbon composites were obtained in situ using a vertical type of spray pyrolysis reactor at $700^{\circ} \mathrm{C}$.

Powder X-ray diffraction (1730 X-ray diffractometer) using $\mathrm{Cu} \mathrm{K} \alpha$ radiation was employed to identify the crys. talline phase of the synthesized materials. The solid morphologies of the resulting composites were observed using a scanning electron microscope (SEM) (Leica/Cambridge Steroscan 440). Transmission electron microscope (TEM) and high resolution (HR) TEM images were obtained from a Philips M12 and JEOL F3000 microscope, respectively. Differential thermal and thermo-gravimetric (DTA-TG) analysis was carried out by using Setaram 92 equipment. The Brunauer-Emmett--Teller (BET) specific surface area was measured by a Quantachrome Nova 1000 gas sorption analyser. The electrochemical characterisations were performed using R2032 coin cells. The anode was prepared by mixing $\mathrm{SnO}_{2}$ or $\mathrm{SnO}_{2}$-carbon composites with $10 \mathrm{wt} \%$ carbon black and $10 \mathrm{wt} . \%$ polyvinylidene fiuoride (PVDF) binder; then drops of $N$-methyl-2-pyrrolidinone (NMP) were added to form a slury with appropriate viscosity. The mixture was then used to coat copper foils to a mass loading of about $1 \mathrm{mg}$ after drying (at $140^{\circ} \mathrm{C}$ ) and compaction (at rate of $150 \mathrm{~kg} \mathrm{~cm}^{-2}$ ). Each coated electrode was assembled into a test coin cell in an argon-filled glove-box (Mbraun, Unilab, USA). The counter electrode was $\mathrm{Li}$ metal and the electrolyte was $1 \mathrm{M} \mathrm{LiPF}_{6}$ dissolved in a $50: 50(\mathrm{v} / \mathrm{v})$ mixture of ethylene carbonate (EC) and dimethyl carbonate (DMC) provided by MERCK $\mathrm{KgaA}$, Germany. The cells were charge-discharged at the constant current density of $0.04 \mathrm{~mA} \mathrm{~cm}^{-2}$ and within the voltw age range of $0.05-1.25 \mathrm{~V}$ at room temperature, to determine the electrochemical characteristics. Cyclic voltammograms (CV) measurements were carried out using an EG\&G potentiostat (model M362) at a scanning rate of $0.1 \mathrm{mV} \mathrm{s}^{-1}$.

\section{Results and discussion}

\subsection{Characterization and morphology}

The amount of tin in the samples was determined by thermogravimetric analysis (TGA) in air. The precursors of $\mathrm{SnCl}_{2} \cdot 2 \mathrm{H}_{2} \mathrm{O} /$ sucrose in weight ratios of 100:0, 60:40, 40:60, and 10:90 resulted in $\mathrm{SnO}_{2}$ without carbon and $\mathrm{SnO}_{2}$-carbon composites containing 89,65 , and $49 \mathrm{wt} \% \mathrm{SnO}_{2}$, respectively. Scanning electron micrographs of the products from the spray pyrolysis process are shown in Fig. 1. All the samples were morphologically alike, presenting a structure resembling broken hollow spheres with porosity on both the inside and the outside particle surfaces (Fig. 1(d)). Fig. 2 shows the $\mathrm{X}$-ray diffraction patterns of samples synthesized by the spray pyrolysis method. All diffiaction patterns show the $\mathrm{SnO}_{2}$ phase as indexed. The $\mathrm{SnO}_{2}$ without carbon (Fig. 2(a)) and $\mathrm{SnO}_{2}$-carbon composites Fig. 2(b)-(d) are revealed as crystalline structures, however, the carbon in the composites was not identified by the XRD diffraction pattern, which indicates the amorphous structure of the carbon. The broad diffraction peaks indicate that the $\mathrm{SnO}_{2}$ is in the form of small

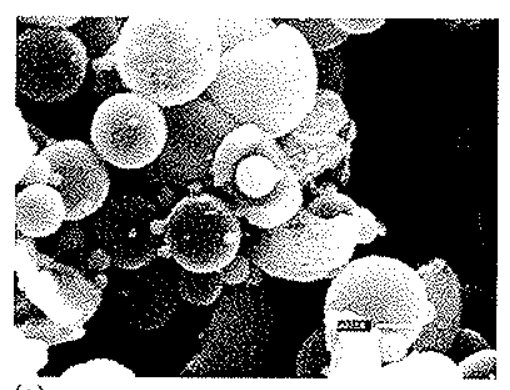

(a)

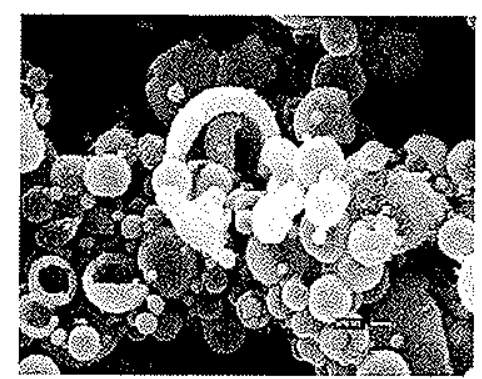

(b)
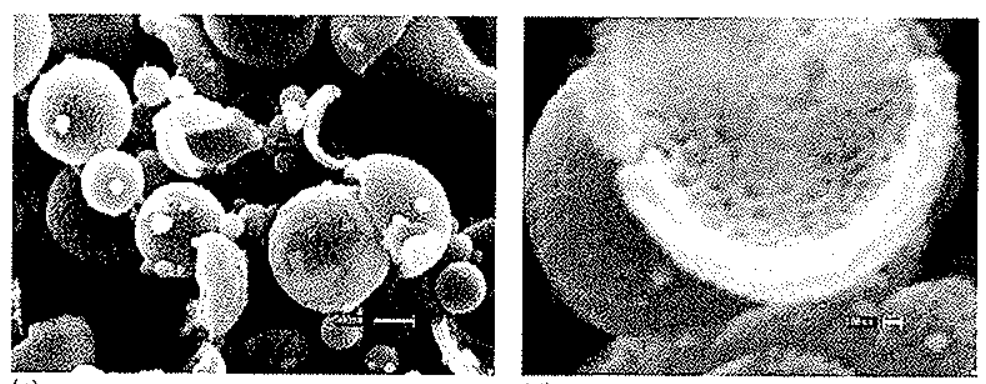

(d)

Fig. 1. SEM images of (a) $\mathrm{SnO}_{2}$ without carbon, and $\mathrm{SnO}_{2}$-carbon composites from the spray pyrolysis process; (b) with $\mathrm{SnO} \mathrm{O}_{2}$ contents of 89 wt.\%; (c) 65 wt. \%; (d) 49 wt. \% (enlarged image). 


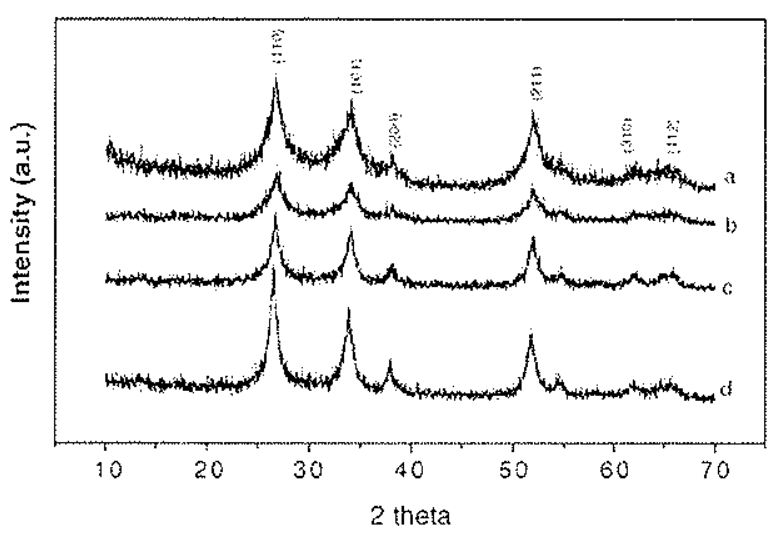

Fig. 2. Xuray powder patterns of sprayed samples: (a) $\mathrm{SnO}_{2}$ without carbon and $\mathrm{SnO}_{2}$-carbon composites; (b) $89 \mathrm{SnO}_{2} \cdot 11 \mathrm{C}$; (c) $65 \mathrm{SnO}_{2} \cdot 35 \mathrm{C}$; and (d) $49 \mathrm{SnO}_{2} \cdot 51 \mathrm{C}$.

crystals in all samples. The grain size for the sprayed samples calculated using the Scherrer formula is in the range of $5-15 \mathrm{~nm}$

The patterns (Fig. 2(b)-(d)) also show that the peak inten. sities increase slightly with increasing carbon content in the composites. Since the spray pyrolysis in situ process causes the chemical reaction to be completed within a very short time, there are large amounts of heat released as the sucrose decomposes, which results in the local temperature increasing very quickly. The more sucrose added in the precursor, the higher the local temperature could go, therefore, the more crystalline $\mathrm{SnO}_{2}$ could form under this higher temperature.

The TEM and HRTEM images shown in Fig. 3 confirmed the calculated $\mathrm{SnO}_{2}$ crystal size of 5-15 nm. The crystalline $\mathrm{SnO}_{2}$ grains are surrounded by amorphous carbon. These images demonstrated the nanostructure of the composites containing crystalline $\mathrm{SnO}_{2}$ which is distributed homogeneously inside the amorphous carbon matrix. The morphological structure of the samples suggests a high specific surface area. Brunauer-Emmett-Teller (BET) specific surface area measurements were conducted, and the results are shown in Table 1. We found that with the carbon content increasing, the specific surface area increased from $20 \mathrm{~m}^{2} \mathrm{~g}^{-1}$ ( $0 \mathrm{wt} \%$ carbon) to $145 \mathrm{~m}^{2} \mathrm{~g}^{-1}$ (51 wt.\% carbon). Compared with $7 \mathrm{~m}^{2} \mathrm{~g}^{-1}$ for the commercial $\mathrm{SnO}_{2}$, there is a significant improvement in the surface area.

Table 1

Results from BET measurement

\begin{tabular}{lcc}
\hline Samples & $\begin{array}{l}\text { Content of carbon } \\
(w t . \%)\end{array}$ & $\begin{array}{l}\text { Specific surface } \\
\text { area }\left(\mathrm{m}^{2} \mathrm{~g}^{-1}\right)\end{array}$ \\
\hline $\begin{array}{c}\text { Commercial } \mathrm{SnO}_{2} \\
\quad \text { Aldrich, } 99 \%)\end{array}$ & 0 & 7.1525 \\
Sprayed $\mathrm{SnO}_{2}$ & 0 & 20.3547 \\
$89 \mathrm{SnO}_{2} \cdot 11 \mathrm{C}$ & 11 & 73.6849 \\
$65 \mathrm{SnO}_{2} \cdot 35 \mathrm{C}$ & 35 & 107.9626 \\
$49 \mathrm{SnO}_{2} \cdot 51 \mathrm{C}$ & 51 & 145.3734 \\
\hline
\end{tabular}

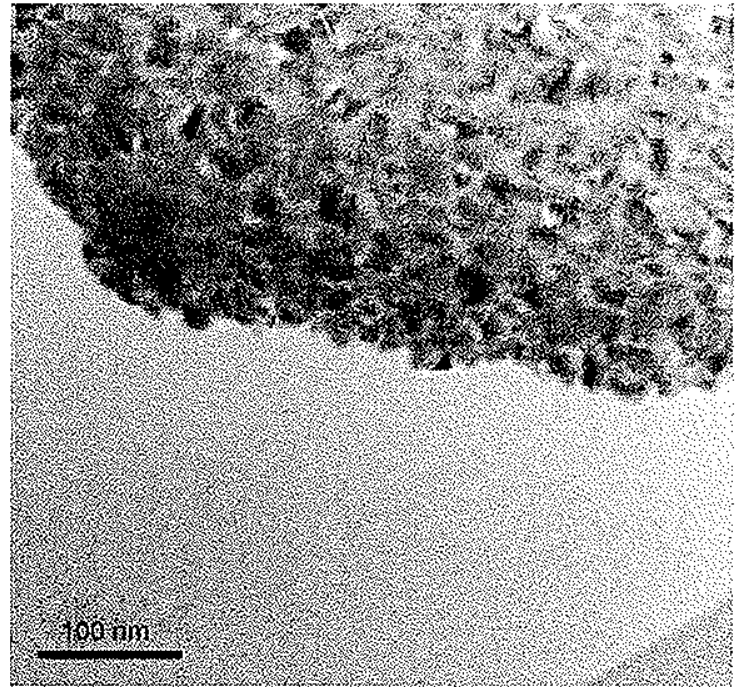

(a)

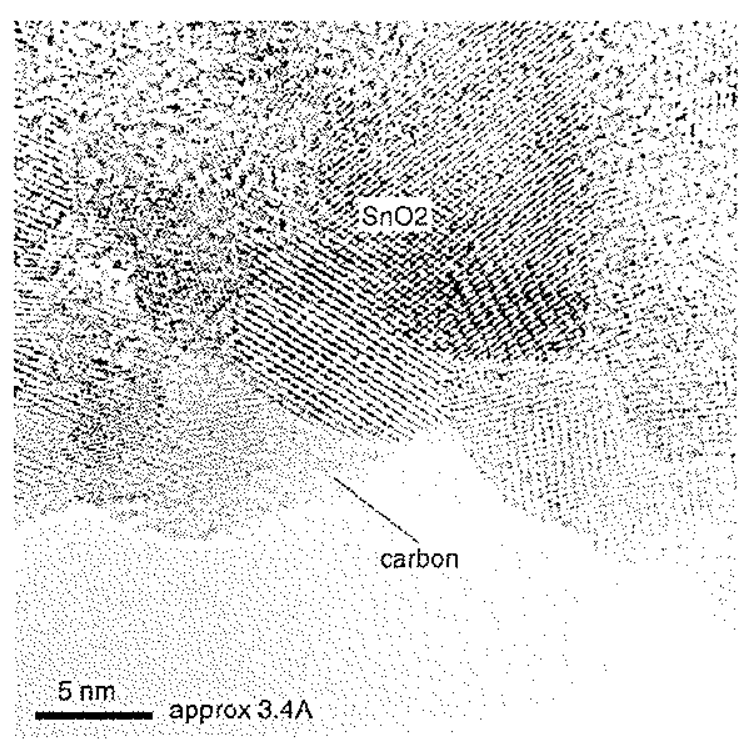

(b)

Fig. 3. TEM (a) and HRTEM (b) images of $65 \mathrm{SnO}_{2} \cdot 35 \mathrm{C}$ composite.

\subsection{Electrochemical properties}

It is believed that $\mathrm{SnO}_{2}$ reacts with lithium in a two-step process as follow [11]:

$$
\begin{aligned}
& \mathrm{SnO}_{2}+4 \mathrm{Li}^{+}+4 \mathrm{e}^{-} \rightarrow \mathrm{Sn}+2 \mathrm{Li}_{2} \mathrm{O} \\
& \mathrm{Sn}+\chi \mathrm{Li}^{+}+\chi \mathrm{e}^{-} \leftrightarrow \mathrm{Li}_{\chi} \mathrm{Sn} \quad 0 \leq \chi \leq 4.4
\end{aligned}
$$

Firstly, the irreversible conversion of $\mathrm{SnO}_{2}$ results in the formation of metallic tin regions dispersed within a $\mathrm{Li}_{2} \mathrm{O}$ matrix; then the lithium alloying/de-alloying with Sn provides the reversible lithium storage capacity of the material [12]. A large volume change occurs in the Sn regions during the lithium insertion and extraction reactions. Even if the $\mathrm{Li}_{2} \mathrm{O}$ matrix slows the aggregation process, it does not prevent it. [13] Consequently, the mechanical stresses lead to 

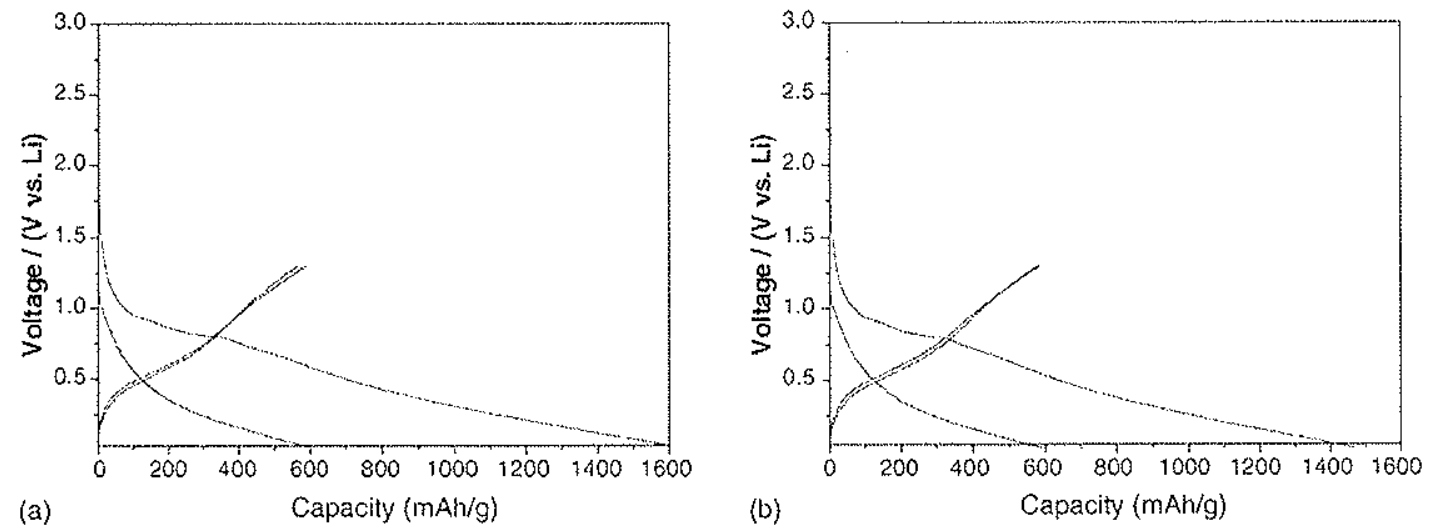

Fig. 4. The first and second discharge and charge curves of (a) nanostructured $\mathrm{SnO}_{2}$ without carbon and (b) $65 \mathrm{SnO}_{2} \cdot 35 \mathrm{C}$ composite at $0.04 \mathrm{~mA} \mathrm{~cm}-2$.
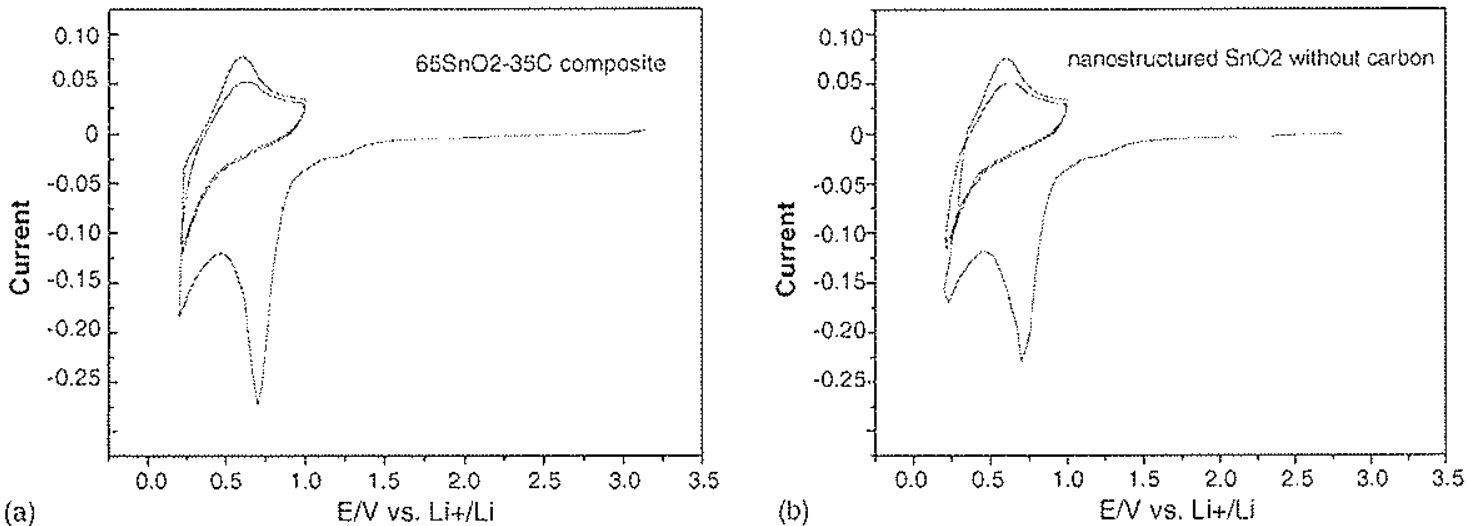

Fig. 5. Cyclic Voltammograms for (a) a nanostructured $65 \mathrm{SnO}_{2} \cdot 35 \mathrm{C}$ composite electrode and (b) a nanostructured $\mathrm{SnO} \mathrm{O}_{2}$ without carbon electrode. Scan rate $0.1 \mathrm{mVs}^{\cdots 1}$.

the electrode cracking and losing electrical contacts between particles, which cause a sharp decrease in capacity.

The specific capacity and cycling stability of nanostructured $\mathrm{SnO}_{2}$ and $\mathrm{SnO}_{2}$-carbon composites electrodes were measured by constant current charge/discharge testing. Fig. 4 shows the first and second charge and discharge curves of the $\mathrm{SnO}_{2}$ and $65 \mathrm{SnO}_{2} \cdot 35 \mathrm{C}$ composite at $0.04 \mathrm{~mA} \mathrm{~cm}^{-2}$ between 0 and $1.25 \mathrm{~V}$. The discharge curves of $\mathrm{SnO}_{2}$ and $65 \mathrm{SnO}_{2} \cdot 35 \mathrm{C}$ composite are fairly similar in appearance, which confirms that only tin in the composite contributes to the electrochemical capacity. There is a plateau in the charging curves below $1 \mathrm{~V}$, which shows $\mathrm{SnO}_{2}$ and $\mathrm{SnO}_{2}$-carbon composite working in the low-potential range $\left(0-1.2 \mathrm{~V}\right.$ versus $\left.\mathrm{Li} / \mathrm{Li}^{+}\right)$. This plateau is believed to correspond to the formation of $\mathrm{Li}_{2} \mathrm{O}$ and $\mathrm{Sn}$ in Eq. (2). The first reversible lithium storage capacity of the $\mathrm{SnO}_{2}$ and the $65 \mathrm{SnO}_{2} \cdot 35 \mathrm{C}$ composite is 589 and $585 \mathrm{mAh}^{-1}$, respectively.

Fig. 5 shows cyclic voltammograms for nanostructured $\mathrm{SnO}_{2}$ and $65 \mathrm{SnO}_{2} \cdot 35 \mathrm{C}$ composite electrodes at a scan rate of $0.1 \mathrm{mV} \mathrm{s}^{-1}$. The $\mathrm{CV}$ curves for both $\mathrm{SnO}_{2}$ and $65 \mathrm{SnO}_{2} \cdot 35 \mathrm{C}$ composite electrodes clearly indicate the irreversible reaction during the first discharge with a reduction peak at $0.7 \mathrm{~V}$. During the following cycles, this peak disappears and only the peaks at low potential $(<0.5 \mathrm{~V})$ corresponding to the $\mathrm{Li}-\mathrm{Sn}$ alloy formation are observed.

Fig. 6 compares the discharge capacity versus the number of charge/discharge cycles for the nano-structured

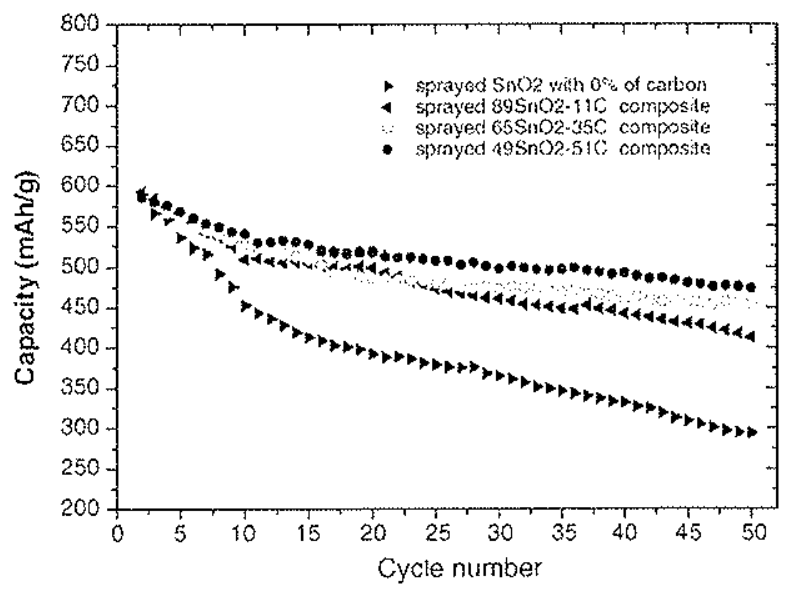

Fig. 6. Discharge capacity vs. cycle number for the potential range from 0.1 to $1.3 \mathrm{~V}$ for the nanostructured $\mathrm{SnO}_{2}$ and $\mathrm{SnO}_{2}$-carbon composites. 
$\mathrm{SnO}_{2}$ and $\mathrm{SnO}_{2}$-carbon composites electrodes. After 50 charge-discharge cycles, $\mathrm{SnO}_{2}, 89 \mathrm{SnO}_{2} \cdot 11 \mathrm{C}, 65 \mathrm{SnO}_{2} \cdot 35 \mathrm{C}$, and $49 \mathrm{SnO}_{2} .51 \mathrm{C}$ electrodes remained at $46,66,77$, and $81 \%$, respectively, of their initial discharging capacity. The composites show a significantly improved cycle-life performance compared with $\mathrm{SnO}_{2}$ without carbon.

We believe that the nanostructure of the sprayed powder and the conductivity and ductility of the carbon matrix are responsible for the good cycle-life performance observed. Firstly, the nano-structured crystalline $\mathrm{SnO}_{2}$ ensures that the Sn region is small enough initially to promote a fast dif. fusion of lithium-ion into the electrode, preventing the $\mathrm{Sn}$ regions from aggregating. Moreover, the composites made by the spray pyrolysis method have a more uniform distribution of $\mathrm{SnO}_{2}$ in the carbon than what could be obtained by mechanical milling. The $\mathrm{SnO}_{2}$ particles are trapped and separated by the carbon, not just mechanically mixed with or dispersed in carbon. The carbon matrix provides an effective cushion against the specific volume changes in the tin regions.

\section{Conclusions}

A series of $\mathrm{SnO}_{2}$-carbon nano-composites were obtained by in situ spray pyrolysis of a mixed solution of $\mathrm{SnCl}_{2} \cdot 2 \mathrm{H}_{2} \mathrm{O}$ and sucrose at $700^{\circ} \mathrm{C}$. The process results in super fine nanocrystalline $\mathrm{SnO}_{2}$, which is distributed homogeneously inside the amorphous carbon matrix. The $\mathrm{SnO}_{2}$ presents a structure resembling broken hollow spheres, which is porous on both the inside and outside particle surfaces. This structure promises a highly developed specific surface area. The XRD patterns and TEM images revealed the $\mathrm{SnO}_{2}$ crystal size is about $5-15 \mathrm{~nm}$. The discharge curves of nanostrucuted $\mathrm{SnO}_{2}$ without carbon and $\mathrm{SnO}_{2}$-carbon composite electrodes are fairly similar in appearance, which confirms that only tin in the composite contributes to the electrochemical ca. pacity. The $\mathrm{SnO}_{2}$-carbon composites showed a significantly improved cycle-life performance compared with $\mathrm{SnO}_{2}$ without carbon. We suggest that the nano-structure of crystalline $\mathrm{SnO}_{2}$ prevents the $\mathrm{Sn}$ regions from aggregating to some extent, and that the presence of the carbon matrix provides an effective cushion against the specific volume changes in the tin regions.

\section{Acknowledgements}

This work was financially supported by the Australian Research Council througin an ARC linkage project (LP0219309) with industry partners: Sons of Gwalia Ltd. and OMG. The authors sincerely thank Dr. Zaiping Guo for valuable discussion and Dr. Tania Silver for help with the editing.

\section{References}

[1] Y. Idota, US Patent 5478671 (1995).

[2] H. Tomyama, Jpn. Patent 07-029608 (1995).

[3] Y. Idota, A. Matsufuji, Y. Mackawa, T. Miyasaka, Science 276 (1997) 1395.

[4] N. Li, C.R. Martin, B. Scrosati, Electrochem. Solid State Lett. 3 (7) (2000) 316.

[5] N. Li, C.J. Patrissi, G. Che, C.R. Martin, J. Electrochem. Soc. 147 (2000) 2044.

[6] Y. Wang, J.Y. Lee, B.H. Chen, Electrochem. Solid State Lett. 6 (1) (2003) A19.

[7] J.Y. Lee, R.F. Zhang, Z.L. Liu, Electrochem. Solid State Lett, 3 (2000) 167.

[8] J.Y. Lee, R.E. Zhang, Z.L, Liu, J. Power Sources 90 (2000) 70.

[9] J. Read, D. Foster, J. Wolfenstine, W. Behl, J. Power Sources 96 (2001) 277.

[10] J. Santos-Pena, I. Brousse, D.M. Schleich, Solid State Ionics 135 (2000) 87.

[11] I.A. Courtney, J.R. Dahn, J. Electrochem. Soc. 144 (1997) 2045.

[12] I.A. Courtney, J.R. Dahn, J. Electrochem. Soc. 144 (1997) 2943.

[13] I.A. Courtney, W.R. McKinnon, J.R. Dahn, J. Electrochem. Soc. 146 (1999) 59. 